WOJCIECH WŁOSKOWICZ

Instytut Języka Polskiego PAN, Kraków

wloskowicz@gmail.com

http://orcid.org/0000-0002-6146-7822
DOI: http://dx.doi.org/10.17651/ONOMAST.63.9

Onomastica LXIII, 2019

PL ISSN 0078-4648

\title{
NAZWY GEOGRAFICZNE HUCULSZCZYZNY W „PRAWDZIE STAROWIEKU” S. VINCENZA (W ŚWIETLE BADAŃ S. HRABCA)
}

Tekst ofiarowany Andrzejowi Ruszczakowi, znawcy i poszukiwaczowi płajów prowadzacych w'siat Vincenza $i$,Wysokiej Połoniny”

Słowa tematyczne: toponim, nazwa geograficzna, Vincenz, Huculszczyzna, „Na wysokiej połoninie"

$$
\text { WSTĘP }^{1}
$$

Tetralogia Stanisława Vincenza „Na wysokiej połoninie” stanowi dla Huculszczyzny epopeję zupełnie pomnikową. Autor, wychowany wśród Hucułów Polak, który odebrał staranne klasyczne wykształcenie, od dzieciństwa zanurzony był (m.in. za sprawą piastunki) w gwarze i mitologii huculskiej. Kosmologię, duchowość i podania Hucułów przeprojektował częściowo na płaszczyznę kulturowych uniwersaliów o antycznym jeszcze rodowodzie, częściowo zaś po polsku sportretował je w duchu dawnej jagiellońskiej wieloetniczności i wielokulturowości. Stwierdzić więc można, że w osobie Stanisława Vincenza i w jego huculskim opus magnum jak w soczewce skupia się cała złożoność językowych i kulturowych kontaktów polsko-ruskich w wymiarze ogólnym, a polsko-huculskich w wymiarze szczególnym. „Na wysokiej połoninie” rozpięte jest przy tym między dość precyzyjną topografią galicyjskiej (a potem międzywojennej polskiej) części Huculszczyzny a baśniowo-mitycznymi krainami Rachmanów i Syroidów gdzieś na wschodzie oraz mglistą huculską ludową geografią ,,szerokiego świata" podobną tej, jaką wydobyć można np. z etnograficznych zapisów Kolberga ${ }^{2}$.

1 Niniejsza publikacja jest efektem grantu „Semantyka i pragmatyka onimiczna. Onomastyczna definicja nazwy własnej a teoria i praktyka polityki nazewniczej”. Instytucja finansująca: Narodowe Centrum Nauki. Nr wniosku: 2018/28/C/HS2/00319.

2 Analizę toponimii obecnej w tekstach ruskiej kultury ludowej zarejestrowanych w poszczególnych tomach „Dzieł wszystkich” Oskara Kolberga podjęła E. Wolnicz-Pawłowska (2001). Lektura „Na wysokiej połoninie” i obserwacja uwiecznionych tam nazw obiektów geograficznych odległych od Huculszczyzny nasuwa nieodparte skojarzenie właśnie z wynikami uzyskanymi przez E. Wolnicz-Pawłowską. Zaznaczyć trzeba jednak, że wspomniana analiza nie objęła „huculskich” tomów dzieł Kolberga — w jej zasięg nie weszły bowiem tomy 54 (Ruś Karpacka, cz. I) i 55 (Ruś Karpacka, cz. II) omawiające Huculszczyznę, Bukowinę i Ruś Węgierską. 
Huculszczyzna jako „bliska egzotyka” wraz ze swą barwną sztuką ludową znana była w przedwojennej Polsce, także jako popularny region letniskowy i turystyczny. Po odcięciu tegoż regionu od polskiego obiegu kulturowego i krajoznawczego szczelną sowiecką granicą „Na wysokiej połoninie” stało się swoistą literacką arką, która w powojennej Polsce w pewnych (ograniczonych wprawdzie) kręgach podtrzymywała, a niekiedy i rozbudzała świadomość i pamięć „egzotycznej” Huculszczyzny.

W okresie PRL w świecie polskiej turystyki karpackiej tęsknotę i ciekawość ku utraconym Karpatom Wschodnim ze szczególną siłą rozpaliło PAX-owskie wydanie Vincenzowskiej epopei, na której kartach część polskich podróżników i czytelników po raz pierwszy spotkała się z toponimią Huculszczyzny (z jednej strony obcą, z drugiej zaś - za sprawą wspólnego wołosko-ruskiego toponimicznego dziedzictwa Beskidów — w pewien sposób jednak znajomą).

„Na wysokiej połoninie” jest więc ważnym ogniwem w historii rozwoju i trwania polskojęzycznej toponimii Huculszczyzny. Językowe właściwości nazw geograficznych zawartych w omawianym dziele nie były przy tym dotąd przedmiotem zainteresowania ani toponomastyki, ani onomastyki literackiej.

Celem niniejszego artykułu jest z jednej strony językoznawczy rekonesans nazw geograficznych Huculszczyzny obecnych w „Prawdzie starowieku” pierwszym tomie serii „Na wysokiej połoninie”, z drugiej zaś materiałowy przyczynek do ogólnej teorii polityki nazewniczej prowadzonej niejako w „,skali mikro" przez autorów tekstów literackich.

\section{AUTOR, DZIEŁO I JEGO WYDANIA}

Stanisław Vincenz urodził się w 1888 roku w Słobodzie Rungurskiej, a więc tuż poza północno-wschodnią dialektologiczną granicą Huculszczyzny, jaką na podstawie badań J. Janowa przyjął w swojej pracy S. Hrabec (1950, s. 7-9). Płynność i umowność owej granicy nie ma jednak większego znaczenia dla ekspozycji młodego Vincenza na gwary huculskie, ponieważ znaczną część dzieciństwa spędził on w sercu Huculszczyzny, w Krzyworówni, gdzie jego dziadek po kądzieli, polski szlachcic, posiadał dobra ziemskie. Zgodnie z klasyfikacją zaproponowaną — także za wynikami Janowa — przez S. Hrabca (1950, s. 29) Krzyworównia leżała w centrum zasięgu gwar wschodniohuculskich. Rolę szczególną w przyswojeniu sobie przez Vincenza gwary (i kultury) huculskiej odegrała zapewne jego krzyworówniańska niania, Hucułka Połahna Słypeńczuk-Rybeńczuk ${ }^{3}$.

3 Refleksje samego Vincenza na temat wpływu opiekunki i informacje o niej zebrali L. Rymarowicz, I. Zełenczuk oraz J. Zełenczuk (2016). 
W czasach galicyjskich i w przedwojennej Polsce Vincenz trwale związany był z obszarem huculskim. W Słobodzie Rungurskiej mieściła się należąca do rodziny Vincenzów kopalnia ropy. W połowie lat 20. we wsi Bystrzec u podnóża Czarnohory miejscowi huculscy budowniczowie wznieśli Vincenzowi dom, w którym zamieszkał on na początku lat 30., pozostając tym samym we wspólnocie komunikatywnej z okolicznymi Hucułami ${ }^{4}$.

„Na wysokiej połoninie” mianem trylogii określane bywa równie często jak mianem tetralogii. Dzieło składa się bowiem z trzech ,,pasm” wydanych w czterech woluminach (liczących łącznie grubo ponad dwa tysiące stron):

t.1: Pasmo I „Prawda starowieku” (I wyd. 1936)

Pasmo II ,Nowe czasy”

t.2: księga I „Zwada” (I wyd. 1970)

t.3: księga II „Listy z nieba” (I wyd. 1974)

t.4: Pasmo III „Barwinkowy wianek” (I wyd. 1979).

Dobrego ogólnego obrazu historii i specyfiki powstawania „Na wysokiej połoninie” dostarcza napisane przez syna autora, prof. A. Vincenza (1983), „Posłowie", pomieszczone w PAX-owskim wydaniu tomu IV.

Pisanie „Połoniny” rozpoczął Vincenz w 1930 roku, a nakładem Towarzystwa Wydawniczego Rój „Prawda starowieku” ukazała się w roku 1936. W pierwotnym zamierzeniu „Barwinkowy wianek” miał być tomem drugim i ostatnim, jednak już w czasie wojny ,wsunęło się” przedeń pasmo „Nowe czasy”, które ostatecznie rozrosło się do dwóch woluminów. Po zakończeniu wojny i po bezpowrotnym opuszczeniu swojej huculskiej „bliższej ojczyzny” Vincenz prace nad epopeją kontynuował aż do śmierci, poprawiając także treść jedynej części wydanej drukiem przed 1939 r. Pierwsze wydanie „Zwady” ukazało się w Londynie w 1970 r., I wyd. „Listów z nieba” — tamże w 1974 r., już po śmierci autora. Oba te tomy Vincenz zdążył jednak przygotować do druku osobiście. Inaczej było w wypadku „Barwinkowego wianka”, którego I wydanie (Londyn 1979) przygotowano na podstawie pozostawionych maszynopisów (Vincenz, 1983, s. 550-552).

Z perspektywy wahań form używanej toponimii istotne jest dyktowanie „Na wysokiej połoninie" jako podstawowy sposób powstawania dzieła, co przekłada się też na „mówiony” język książki:

4 Związki Vincenza z Huculszczyzną, a w szczególności ze wsią Bystrzec, dokumentują liczne artykuły i opracowania publikowane na łamach krajoznawczego periodyku „Płaj” (przede wszystkim wskazać tu należy teksty A. Ruszczaka i L. Rymarowicza). Całościową biografię autora „Połoniny” opublikowała M. Ołdakowska-Kuflowa (2006). 
Toteż całe Na wysokiej poloninie jest tekstem mówionym, jednym wielkim opowiadaniem, rozmową z czytelnikiem. O tym należy stale pamiętać. Gdyż także pisane było w ten sposób: najpierw notowane całkiem nieczytelnym pismem, czymś w rodzaju prywatnej stenografii, jako pierwszy brulion, z którego dyktował potem mojej Matce na maszynę tekst mniej więcej definitywny. Niektóre teksty były tak dyktowane dwa albo i trzy razy, a wszystkie powstawały jako teksty ustne, mówione. Łatwo się o tym przekonać czytając je na głos. I to także odpowiadało wewnętrznemu charakterowi dzieła, którego autor uważał się za ostatniego opowiadacza huculskiego. Wszystkie teksty też lub niemal wszystkie były następnie wielokrotnie odczytywane głośno przyjaciołom albo członkom najbliższej rodziny, a stąd znów dalsze poprawki i uzupełnienia. Ojciec lubił też wyciągać z szafy niby już gotowe rękopisy i wprowadzać w nich dalsze poprawki, których oczywiście nie przenosił do kopii (Vincenz, 1983, s. 555).

W PRL obowiązywał na Vincenza nieoficjalny zapis. Jak zaznacza A. Vincenz (1983, s. 558-559), wprawdzie w roku 1957 S. Vincenz otrzymał od PIW-u propozycję wydania całości „Na wysokiej połoninie”, ale już w $1961 \mathrm{r}$. nadeszła z wydawnictwa wiadomość, że rzecz nie dojdzie do skutku, co uzasadniano „specjalnym charakterem książki” i „zmniejszeniem przydziału papieru”.

Ostatecznie „wydanie krajowe” powierzono PAX-owi. „Prawdę starowieku” wydał on w $1980 \mathrm{r}$. w postaci poprawionej jeszcze przez samego autora (zmienionej względem wydania z 1936 r.), natomiast podstawą wydania tomów 2-4 (odpowiednio: 1981, 1982, 1983) były pierwsze wydania londyńskie, do których wprowadzono drobne zmiany redakcyjne i korektorskie.

Na uwagę zasługują informacje zawarte w notach redakcyjnych do 2 i 3 tomu wydania PAX-owskiego. W obu jest mowa o dostosowaniu pisowni do „obowiązujących norm”. W obu też wypadkach „respektowano formy polszczyzny regionalnej” oraz formy oboczne: „Synyci i Synycie, rechotać i rzechotać itp.” (nota do t. 2, s. 605) oraz „Riabyniec i Rabyniec, Tudiów i Tiudów, Sygiet i Siget, Debreczyn, Debrecyn, Debrecen, sczeznyk i szczeznyk itp." (nota do t. 3, s. 572). W dalszej części tej pracy wyekscerpowany materiał pozwoli wskazać na znaczną pisowniową wariantywność toponimii w tomie pierwszym.

Wszystkie cztery PAX-owskie woluminy miały — niewielki jak na warunki PRL — nakład 10 tys. egzemplarzy. Niemniej jednak to właśnie edycja z początku lat 80 . XX w. w wielu przypadkach stała się dla zainteresowanego kręgu odbiorców pierwszą szansą na zetknięcie się z dziełem Vincenza i z Huculszczyzną (co wpłynęło też na wybór tego wydania jako źródła ekscerpcji materiału). Ostatnim wydaniem krajowym wszystkich czterech tomów była edycja przygotowana przez Fundację Pogranicze (Sejny: 2002, 2003, 2004, 2005).

Ważnym rozdziałem w historii rozpowszechnienia i upowszechnienia Vincenzowskiej tetralogii jest nabycie przez państwo polskie autorskich praw majątkowych do omawianego dzieła. W ramach programu „Udostępnianie piśmiennictwa" w latach 2014-2016 dokonał tego Instytut Książki, dzięki czemu zdigitalizowane tomy wydania PAX-owskiego dostępne są obecnie na licencji 
Creative Commons Uznanie autorstwa 3.0 w serwisie Biblioteki Narodowej POLONA ${ }^{5}$. Skany te, przekonwertowane do formatu $\mathrm{Dj} \mathrm{Vu}$, dostępne są też w zasobach polskiej Wikipedii.

\section{„NA WYSOKIEJ POŁONINIE” JAKO ŹRÓDŁO W BADANIACH JĘZYKOZNAWCZYCH}

Na temat „Na wysokiej połoninie” licznie wypowiadali się w swoich pracach literaturoznawcy. Z perspektywy empirycznie zorientowanej lingwistyki ich rozważania często mają jednak ograniczoną wartość poznawczą ${ }^{6}$.

Językoznawcy tematu „Połoniny” nie podejmowali natomiast niemal wcale i tylko w minimalnym zakresie stała się ona źródłem materiału badawczego. W tym kontekście wspomnieć wypada o dwóch pracach: „Nazwach geograficznych Huculszczyzny” (Hrabec, 1950) oraz „Stylizacji huculskiej” (Brzezina, 1992).

Jako poboczne źródło materiału toponimicznego (w bardzo ograniczonym zakresie) wyzyskał „Na wysokiej połoninie” S. Hrabec. Korzystał przy tym, rzecz jasna, z I wydania „Prawdy starowieku” z 1936 r. ${ }^{7}$ W rozdziale „Huculskie słownictwo topograficzne" w objaśnieniach kilku apelatywów powołał się na słowniczek wyrazów huculskich towarzyszący „Prawdzie starowieku”. W kilku przypadkach posłużył się też „Połoniną” przy objaśnianiu etymologii toponimów lub w ich materiałowej dokumentacji. Nazwę części wsi Foszewa wywodzi więc Hrabec (1950, s. 219) od n. os. *Fosz, którą zestawia z obecną u Vincenza n. os. Foka. Przytacza też za Vincenzem (niejako na marginesie) ludową etymologię n. góry Ihrec:

Inną, bardziej poetycką, ale też mało prawdopodobną etymologię nazwy Ihrec podaje S. Vincenz: „A wciąż palili z pistoletów, aż dymy z Ihreca kurzyły się lasami. Hulali tak i świętowali święto zbudzenia się wiosny, święto rozigrania się ludzi lasowych, puszczowych junaków, Stąd też, powiadają, od tej zabawy, od tego igrania, góra sama nazwę Ihrec otrzymała" (Hrabec, 1950, s. 156).

Podsumowując: „Połonina” została wprawdzie przez przedwojenne językoznawstwo (a dokładniej przez onomastykę) dostrzeżona jako potencjalne źródło materiału, wykorzystana została natomiast w stopniu mniej niż niewielkim.

5 Udostępnianie piśmiennictwa, https://instytutksiazki.pl/p,otwarte-zasoby.html (dostęp: 26 III 2019).

${ }_{6}$ Wiele informacji na temat Vincenza i jego twórczości (w tym bibliografię podmiotową i przedmiotową) zawiera powstały w ramach grantu NPRH portal www.vincenz.pl (dostęp: 26 III 2019).

7 „Nazwy geograficzne Huculszczyzny” powstały w latach 1936-39 jako rozprawa doktorska przygotowana na UJK we Lwowie. Druk książki miał się rozpocząć we wrześniu 1939 r. 
Co więcej, toponimia „Prawdy starowieku” sama w sobie nie stała się przy tym przedmiotem badań.

Materiał z „Połoniny” nie wszedł też w zakres analizy dokonanej przez M. Brzezinę (1992) w jej „Stylizacji huculskiej”. Praca ta poświęcona została leksyce i onimii jako płaszczyźnie huculskiej stylizacji językowej obecnej w polskiej literaturze pięknej. Z oczywistych względów Brzezina objęła ekscerpcją zasadniczo dzieła przedwojenne. Opracowana przez nią kartoteka zawierała materiał wydobyty z „Na wysokiej połoninie”, jednak — jak w swym studium wyjaśnia badaczka - rozmiarem swym przerastał on łączną objętość ekscerpcji przeprowadzonej z wszystkich innych źródeł, co doprowadziło Brzezinę do decyzji o pozostawieniu toponimii Vincenzowskiej przyszłym badaniom. W rezultacie brak jest w piśmiennictwie stosownych ustaleń dotyczących „Połoniny”.

\section{OGÓLNE UWAGI O TOPONIMII HUCULSZCZYZNY W TEKSTACH JĘZYKA POLSKIEGO}

W dziele Vincenza jako tekście polskojęzycznym (z fragmentami ukraińskojęzycznymi lub gwarowymi huculskimi) pojawiają się nazwy geograficzne głównie wołoskiej i ruskiej proweniencji, na Huculszczyźnie (w wyniku adaptacji lub od swego powstania) używane w formie zgodnej z fonetyką, fonologią i słowotwórstwem gwar huculskich. W oczywisty sposób otwiera to problem ewentualnej adaptacji endonimicznych form huculskich do systemu językowego polszczyzny. Pod tym względem toponimia „Na wysokiej połoninie” wpisuje się w dużo szerszy kontekst językowych właściwości nazw geograficznych Huculszczyzny używanych w tekstach polskich.

Kontekst ten determinowany jest z kolei przez wielowiekowe polsko-ruskie sąsiedztwo i kontakty językowe zarówno na terenach przejściowych, jak i obszarach „wysuniętej” obecności (skierowany na zachód ruski klin językowy w Beskidach oraz powstałe w różnych okresach i okolicznościach polskie ,wyspowe" osadnictwo na Ukrainie) $)^{8}$.

Z jednej strony polszczyzna, zwłaszcza kresowa, dysponowała utartymi schematami polonizacyjnymi (wynikającymi m.in. z systemowych analogii między językiem polskim a językiem ukraińskim i jego gwarami), z drugiej zaś strony nierzadkie było w polszczyźnie używanie nazw o charakterze hybrydalnym polsko-ukraińskim. Ponadto pewna polsko-ukraińska „świadomość kontrastywna”

8 Te relacje językowe na płaszczyźnie toponimicznej opisują m.in. W. Makarski (1986), B. Czopek (1988), J. Rieger (1993, 1994, 1995), E. Wolnicz-Pawłowska (1998a, 1998b), T. Pluskota (1998), W. Decyk-Zięba (2004), W. Wysoczański (2006) oraz oczywiście S. Hrabec (1950). 
rodzimych użytkowników (kresowej) polszczyzny ułatwiała — w razie konieczności - rozróżnienie wariantu polskiego i ukraińskiego. Przełożyło się to na używane w tekstach języka polskiego formy toponimów z obszaru huculskiego:

„polska toponimia Huculszczyzny” pod względem cech systemowych (językowych) wykazuje się dużą heterogenicznością. Nie można zatem stwierdzić, iż w odniesieniu do toponimii Huculszczyzny język polski (czyli w istocie ogół jego użytkowników) wykazuje jakieś jednoznaczne globalne tendencje: do adaptacji (polonizacji) albo do zapożyczania (endonimicznych form) nazw nawet pomimo ich wyraźnej obcości systemowej. Każda z nazw geograficznych Huculszczyzny w historii kształtowania się polskiego zbiorowego uzusu toponimicznego miała swoje własne, indywidualne losy. Habent sua fata nomina (Włoskowicz, 2017, s. 557-558).

Nie należy przypuszczać, by nazewnictwo obecne na mapach miało szczególnie istotny wpływ na formy toponimii używane przez samego Vincenza, przy czym heterogeniczność tych ostatnich nie odbiega od tego, co znaleźć można w kartografii ${ }^{9}$.

\section{ŹRÓDŁO I PREZENTACJA MATERIAŁU ${ }^{10}$}

Zgodnie z tytułem pracy ekscerpcją objęto I tom („Prawda starowieku”) „Na wysokiej połoninie". Jako źródło materiału wykorzystano wydanie PAX-owskie $^{11}$, którego nie kolacjonowano z I wydaniem z 1936 r. ani z wydaniem z 2002 r. (Sejny: Fundacja Pogranicze). O ile porównanie wydania przedwojennego z wydaniem PAX-owskim (wersja „Prawdy starowieku” przepracowana przez samego Vincenza) mogłoby ujawnić pewne pojedyncze modyfikacje odautorskie, o tyle kolacjonowanie $\mathrm{z}$ wydaniem sejneńskim doprowadzić mogłoby jedynie do wniosków dotyczących ingerencji redakcyjnych. Przede wszystkim jednak uzyskane wyniki stanowić mają fragment szerszych obserwacji dotyczących kształtowania się nazewnictwa geograficznego Huculszczyzny w języku polskim, wobec czego ekscerpcję można było ograniczyć do wydania, które najpowszechniej i najintensywniej przełożyło się na powojenną recepcję „Prawdy starowieku". Ekscerpcję ograniczono do nazw obiektów z obszaru Huculszczyzny i do pojedynczych nazw z obszarów przyległych. Formy hasłowe poprzedzono gwiazdką $(*)$, jeśli mianownikowej postaci nazwy nie wynotowano bezpośrednio $\mathrm{z}$ tekstu Vincenza ani nie jest ona możliwa do ustalenia na podstawie

9 Językowe właściwości toponimii Huculszczyzny obecnej na mapach austro-węgierskich i polskich omówiono w osobnych opracowaniach (Włoskowicz, 2015, 2018).

${ }^{10} \mathrm{~W}$ wybranych hasłach w nawiasach ostrokątnych zaznaczono typ obiektu $(<\mathrm{p} / \mathrm{r}>=$ potok lub rzeka). Krzyżykiem (\#) oznaczono nazwy obiektów spoza północnej dialektologicznej granicy Huculszczyzny przyjętej przez S. Hrabca (1950, s. 7-9).

11 Vincenz, S. (1980). „Na wysokiej połoninie”, „Prawda starowieku”, „Obrazy, dumy i gawędy z Wierchowiny Huculskiej”. Warszawa: Instytut Wydawniczy PAX. 
obecnej w nim formy biernika. Prezentacja materiału nie zawiera informacji o frekwencji nazwy w analizowanym źródle. Za pomocą numerów stron lokalizowano wybrane (czasem tylko pierwsze) wystąpienia danej formy — poniższe zestawienie nie ma więc walorów pełnego skorowidza nazw geograficznych w „Prawdzie starowieku”.

Baba Lodowa ${ }^{12}$ 325, Baby Lodowej 325, Babie Lodowej (C, Ms) 88, 245, 323, na Babę Lodowa 322; Paluba (M sg) 326; Lodowa Baba Eudokia 492; Popadii lodowej (D) 323; „na Babie Lodowej, bo mrozi, Łudowej, bo łudzi” 325.

*Bednarówka, Bednarówki (D sg) 341.

Berezów, „ku tym dziwnym osadom wojackim, Berezowom, jak się tam one zwą wszystkie: Berezów Wyżny, Średni, Niżny, Bania Berezowska" 41, Berezowa (D) 364, „z osady szlacheckiej Berezowa” 506, Berezowie (Ms) 364.

Bereżnica (M sg) <rzeka $>155$, Bereżnica to jar 117, Bereżnicy (D, Ms) 88, 117, 118, 312, 422, Bereżnicę (B) 117; Bereźnico (W) <p/r> 354.

*Biała Kobyla, Biata Kobyta (N) 215.

Biała Krynica <źródło> 219, Białej Krynicy (D) 219, Biała Krynica (N) 277.

Biała Rzeka, Białej Rzeki (D) 326, Biała Rzeke (B) 262, Dolna i Biała Rzeka 523, ,znad Dolnej i znad Biatej Rzeki” 523; nad Biatym Czeremoszem 330, „spadają łagodnie w długich zboczach ku Białemu Czeremoszowi, a ścięte są krótkim spadem w stronę Czarnej Rzeki" 325.

\#Bolechów (M־B sg) 340 .

*Brustury, gdzieś na Brusturach 81.

Bukowiec, przez przełęcz Bukowca 42, 64, 397, na stokach Bukowca 65, od Bukowca 65, od szczytu Bukowca 68, połonina Bukowiec 74, na Bukowiec 74, 115, aż po Bukowiec 272, napadli Dmytryka po drodze na Bukowcu 343.

*Burkut, do Burkutu 274, za Burkutem 271, ,nazywa się z węgierska Borkut to jest źródło winne" 274; w potoku borkuckim pod Łukawicami 353.

Bystrzec $<$ rzeka $>28,30$, nad rzeczką Bystrec 117, przy ujściu Bystrzeca 28, nad ujściem Bystreca 90, z Bystreca <osiedle> 424, Bystreca (D) 117, 121, Bystrzeca (D) 29, 31, ku Bystrzecowi 222, nad Bystrecem pod Czarnohorą 115, Bystrzycu $(\mathrm{W})<\mathrm{p} / \mathrm{r}>354$.

*Bystrzyca, wody Bystrzycy i Prutu 246, nad Bystrzycami (pl) 127.

Cerkwy Doboszowe (M pl) 54, cerkwy Doboszowe 215, na Cerkwy 68, 349.

Cisa 208, Cisy (D sg) 116, 194, 195, Cisie (C) 208, na rzece Cisie 114, 447.

12 Forma opatrzona w książce przypisem: „(...) Pierwotne i właściwe nazwanie wyżej wymienionego grzbietu jest Baba Łuduwa, co znaczyć może z wołoska: bezkształtna, nieforemna, pałuba. — Por. także huculskie słowo «załuda», oznacza coś nieruchawego, gnuśnego" (326). 
Czarny Czeremosz, „Czarny Czeremosz, zwany też Czarna Rzeka” 42, Czeremoszu Czarnego (D) 64, nad Czarnym Czeremoszem 325; Rzeka Czarna 42, Czarnej Rzeki (D) 84, 325, nad Czarną Rzekę 274, nad Czarną Rzeka 42, $232,327$.

*Czarny Gruń, pod Czarnym Gruniem za Bereżnicą 504.

Czarnohora, Czarnohory (D), Czarnohorze (C), w Czarnohorę, na Czarnohore, pod Czarnohora, w Czarnohorze, na Czarnohorze, ku Czarnohorom (pl) 253, w Czarnohory (pl) 181, w Czarne Hory $315^{13}$.

Czerdak 28, w karczmie zwanej Czerdak 28, Czerdaka (D) 22, 29, 30, 31, 32, 36, 41, ku Czerdakowi 35, na Czerdaku 28.

Czeremosz 42, Czeremoszu (D) 35, Czeremoszowi (C) 65, nad rzeką Czeremoszem 270, nad Czeremoszami 127, nad obu Czeremoszami 46, dzielącego oba Czeremosze 325; Rzeka, z Kut w górę Rzeki 274, ,z Rożna, znad Dolnej Rzeki" 430; w pasmie gór czeremoskich 445.

Czerłeny, potok Czerłeny 117, potoku Czerłenego 118, u wylotu Czerłenego 118.

Czuriek, „,największe jezioro w Czarnohorze, Szybene, zwane w dawnych czasach Czuriek' 234, nad jeziorem Czuriekiem 524, ,nad jeziorem, nad Czuriekiem" 547.

Czywczyn, na Czywczyn (B) 347, na Czywczynie (Ms) 298; w górach Czywczyńskich 165; w Czywczyny 181, w Czywczynach 171.

*Dancyrski, z Dancyrskiego 446, na Dancerskim 20; z Dancyrza 446; do przełęczy Dancyrskiej 446.

Dietul, na kiczerze zwanej Dietut 118, na Dietule 118.

Doboszanka <góra> 215, szczytu nazwanego odtąd Doboszanką 244, w jaskiniach zwanych Doboszankami 244.

Dobryńka (M sg) <p/r>354.

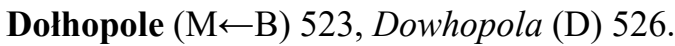

*Dubowe, na miejsce zwane Dubowem 330, na miejscu Dubowem 528.

*Dzembronia, Dzembroni (D) 82, 93, 120, Dzembronię (B) 89, Dzembronia (N) 88, 95, Dzembronio (W) $<\mathrm{p} / \mathrm{r}>354$.

Dzial $(\mathrm{M}$ B) 499, na szczycie Działu 497.

*Fereskula, z Fereskuli 98, do Foreskuty 330.

*Gadżyna, z Gadżyny 18, na Gadżynę 18, źródło doboszowe pod Gadżyna 552, Gadżnie (W pl?) <p/r>354.

* Glyfa, na Gtyfie w Żabiem 245.

Gorgany 166, 311, po rumowiskach Gorganów 38, w Gorganach 215, 244.

${ }^{13}$ Nazwa ma w źródle b. dużą frekwencję i regularną odmianę, w związku z czym podano tylko lokalizacje form nietypowych. 
Grahit 300, od Grahitu kosmackiego 311, ku Grahitowi 302.

Gromotny $<\mathrm{p} / \mathrm{r}>354$.

Gutyn Tomnatyk 192, na Gutyn Tomnatyk (B) 207, 221, pod Gutyn Tomnatyk (B) 202, pod Gutyn Tomnatykiem (N) 198, 204, na Gutyn Tomnatyku (Ms) 193, 200, ze szczytu Gutyna (D) 194, ku Gutynowi (C) 204, na Gutyn (B) 204, pod Gutynem (N) 193, 197, 203, na Gutynie (Ms) 198, 202, 207, 563, Tomnatyk (M) 194.

*Hnatiesa, na Hnatiese 88, na dalekiej Hnatiesie 84, po Hnatiesie 88.

Holowy (M pl) 327, ze słynnej osady Holowy 323, Holów (D) 21, 77, 92, 108, na Hołowach 20, 326, ,znaleźli trzy głowy ludzkie, wypełnione złotem. I od tych głów nazwali to miejsce - Hołowy" 328.

Hordje, aż pod Hordje 220, na Hordjem między Kosmaczem a Worochtą 245.

Hostowy (M sg) <p/r> 354, na połoninę Hostowy 384, z Hostowego 424, ku Hostowemu 357, aż pod Hostowy (B sg) 503, pod szczytem Hostowym (N) 358, na Hostowym (Ms) 372.

*Howerla, Howerli (D) 242, ku przełęczy Howerli 296, na Howerli (Ms) 215.

*Huculia, Huculii (D sg) 35.

Huk, wodospadem, który nazywają $H u k 43$.

Ihrec, pod samym szczytem góry Ihrec 156, na wierch Ihreca 47, na połoninie Ihreca 245, z Ihreca 245, 297, ku Ihrecowi 246, nad Ihrecem (N) 157, na Ihrecu (Ms) 101, 245, 246, 453, „od tej zabawy, od tego igrania góra sama nazwę Ihrec otrzymała" 246.

Ihrowyszcze, „na jakąś równą polanę - taką jak Ihrowyszcze na Prosicznym” 464.

*IIcia, Ilcio (W) $<\mathrm{p} / \mathrm{r}>354$.

*Jabłonica, z Jabłonicy 422.

\#*Jabłonów, na Jabłonowie pokuckim 287, w Jabtonowie 506.

*Jamna, pod Jamna (N) 321, w Jamnej (Ms) 55, w Jamnie (Ms) 215.

Jasienów 90, osada Jasienowo 64, Jasienowa (D) 90, 157, Jasienowo (B) 109, 111, 129, 139, 258, 394, nad Jasienowem (N) 222, w Jasienowie (Ms) 73, 84, 85, 105, 167, 258, na Jasienowie (Ms) 90, 369, 370, w Jasieniowie (Ms) 363; na Jasienowska kiczerę 95.

Jasień (M־B) 447, Jasienia (D) 449, w Jasieniu (Ms) 288, 447, do Jasienia wegierskiego (D) 105, do Jasienia Wegierskiego (D) 446, 447, w Jasieniu wegierskim (Ms) 82, 113, 288.

Jaworowo (M૯B) 76, z Jaworowa 74, w Jaworowie 94.

Jaworze, na polanie zwanej Jaworze 23, z Jaworza pod Czarnohorą 98.

Jezierneński $<\mathrm{p} / \mathrm{r}>354$.

Kamieniec, ku połoninie Kamieniec 344, niedaleko Kamieńca 373, ze stromego zbocza Kamieńca 348, na Kamieńcu 347. 
*Kiczera, z wierzchołka Kiczery (D) 71, ponad Kiczera (N) 68, na Kiczerze nad ujściem Bystreca 90; do swojej kiczery jasienowskiej 84, na Kiczerę Szkindowa 481.

*Kiedrowata, z Kiedrowatej 314, 316, 321, na Kiedrowata 315, na Kiedrowatej 215, 259, 260, chodził po Kiedrowatej 233, na Kiedrowatej połoninie 315; *Kiedrowaty, prawy brzeg Kiziej, zwany Kiedrowatym 230, na Kiedrowatym 230, 231, 242, 284.

Kizia 242, potok Kizia 19, Kiziej (D) 230, wody Kiziej ze skał spływają 226, wodospady Kiziej 317, ku Kiziej połoninie 226, na Kizia 221, 229, na połoninę Kizia 226, na połoninie Kiziej 18, na Kiziej nie będzie już połoniny pańskiej 226; huki Kiziego potoku 260.

*Kizie Ułohy, na Kizich Ułohach 296, ,z wjazdu na skalistym czerwonym ułogu. Biegli po tych ułogach, skakali z głazu na głaz" 296.

Komarniczny, poza gruń Komarniczny 469, na Komarniczny 486.

Kosmacz, wieś Kosmacz 300, Kosmacza (D) 302, 312, ku Kosmaczowi 302, na Kosmacz 494, między Kosmaczem (N) 245, 302, w Kosmaczu 285, 312, 315.

Kosów 256, Kosowa (D) 21, 65, 120, ku Kosowowi 42, w Kosowie 82, 106, 267.

Kostrycz (fem. M־B) 42, na stoku Kostryczy 118, na Kostrycz 18, na Kostry$c z y$ (Ms) 226.

*Koszelewo, z Koszelewa na Zabrodziu 154.

Koszeryszcze 118, do Koszeryszcza 117, na Koszeryszczu 90, 117.

Krasnojyla, osiedle Krasnojyla 263, z Krasnojyli 109, „w Riczce-Krasnojyli, którą i do teraz Riczka Diduszkowa zowią” 262, „bardzo wielka jodła. Z niej to właśnie wtedy zbudowano tę cerkiewkę, a z grubego pnia-odziomka zrobiono ołtarz. Od tej też jodły nazwano parafię i osiedle Krasnojyla, co znaczy piękna jodła" 330; do cerkwi Krasnojylskiej 77.

Krasny Luh, tym to jarem Czeremoszu, zwanym Krasny Łuh 43, od Kraśneho Łuhu 85.

*Krzemienisty, pod Krzemienistem 335, „pod Skupową, nad Krzemienistym” 339, na Krzemienistym 442; pod Kremenystym 20.

Kremenica 513, z Kremenicy 521, z Kremienicy 555, pod Kremenice 515, 516, pod Kremenica 513, na Kremienicy 525.

Kryniczny $<\mathrm{p} / \mathrm{r}>354$.

*Krynta, ku pasmom Kryntej (D) 222, z Kryntej 260, 264, ku Kryntej 251, ku Krętej 85, Krynta (B) 42, 249, na Kryntej (Ms) 90.

* Krzesło Doboszowe, niedaleko Krzesta Doboszowego 315, aż pod to Krzesto skalne 317.

*Krzywa, z Krzywej <osiedle $>424$.

*Krzyworównia, Krzyworówni (D) 19, 21, 29, 48, 49, 64, 68, 92, 107, 117, 118, 153, 157, 158, 245, 258, przez Krzyworównię 64, na Krzyworównię 139, 
w Krzyworówni 29, 48, 85, 105, 116, 121, 130, 153, 156, 258, 259, 265, 266, 269, 272, 327, na Krzyworówni 136.

*Kuty (pl), Kut (D) 64, 68, 91, 232, 255, 274, Kutach (Ms) 254.

Lelkowy (M૯B) 486, Lelkowy $<\mathrm{p} / \mathrm{r}>354$; zza Lelkowej góry 349.

*Liszniowa, połoniny Liszniowej (D) 311 .

Lodowy $<\mathrm{p} / \mathrm{r}>354$.

Lostun, na połoninie Łostun 362, 373, z Łostunu 395, pod Łostun 394, na Łostunie 394, 419.

Luhy, do górskiej wsi Łuhy 89.

*Lukawice, na przełęcz niedaleko Łukawic 352, od strony Łukawic 357, w potoku borkuckim pod Eukawicami 353, na szerokiej połoninie na Eukawicach za Burkutem 271.

Lysyna < góra $>300$.

Markówka, na samym końcu osiedla zwanego Markówka 219, z Markówki 286, na Markówce 219.

Marmurowy $<\mathrm{p} / \mathrm{r}>354$.

*Marysze(w)ska, z Maryszeskiej 18, na Maryszeska 18, przez przełęcz Maryszewska 220.

Medweżyk, grumyk <sic!> Medweżyk 513.

Młaki (pl, M־B) 18.

*Mokryn, w głębi skał Mokrynu 55.

Munczel 461, Munczela (D) 230, na ogromnej trawiastej połoninie Munczela 220, na stoki Munczela wegierskiego 205, ku Munczelowi 243, pod Munczelem 215, na ogromnym Munczelu 460.

jeziorko Niesamowite 304, jeziorka Niesamowitego (D) 305, w jezioro Niesamowite 306; gdzieś jakby na dnie Niesamowitym 305.

Oziernyj (M־B) 18.

Pajęczy $<\mathrm{p} / \mathrm{r}>354$.

*Palenica, pod przełęczą Palenicy 35, w głuszy Palenicy 165, od Palenicy 237, pod Palenica.

Pawi $<\mathrm{p} / \mathrm{r}>354$.

\#Peczeniżyn 219, Peczeniżyna (D) 300.

*Perechrestny, od Perechrestnego 422, na Perechrestnym 551.

*Pietros, na skałach Pietrosa 296, pod Pietrosem <czarnohorskim> 295, pod Pietrosem rodneńskim 244.

Pisany Kamień 170, połonina Pisany Kamień 74, 167, u podnóża połoniny $P i$ sany Kamień 397, Pisanego Kamienia (D) 77, 227, ku Pisanemu Kamieniowi 224, na Pisany Kamień 68, pod Pisanym Kamieniem 244, na Pisanym Kamieniu 222, na Kamieniu Pisanym 299.

Pistyń (M־B) 497, z Pistynia 514, w Pistyniu 506. 
*Pohoriwka, z Pohoriwki 18, na Pohoriwke 18.

Pohorylec, potok Pohorylec 202.

*Poleny węgierskie, w Polenach węgierskich 106; poszli więc dalej górami Polańskimi 238, w górach Ruspolańskich 241.

*Popadia, w skałach Popadii 171, koło Popadii 357, na Popadii 298.

Popadyniec, potok Popadyniec 353, z Popadyńca 397, w borach nad Popadyńcem 347.

*Pop Iwan, wypływa z Pop Iwana 202, od szczytu Popa Iwana 234, na stokach Pop Iwana 300, na Pop-Iwanie 460.

Probijny $<$ p/r $>354$, przez potok Probijny 343; „ku źródłom Probijnej, towarzyszki Białej Rzeki” 353.

Prosicznyj, ,płaj, przesieczony przez puszczę i zwany stąd Prosicznyj” 329, z Prosicznego 329, Prosicznym (N) 329, 335, 337, siadła na górze na Prosicznym 387.

Prut (M־B) 258, Prutu (D) 46, ku Prutowi 219, 300, nad Prutem 55, 127, 214, 215.

*Psariwka, z Psariwki 18, na Psariwke 18.

*Puszkar, za Puszkarem 246.

Putylla, niedaleko ujścia potoku Putylla 229, przy ujściu Putylli 229, „hen na Bukowinie, nad Putyllami” (pl) 487.

Rabyniec $<$ rzeka $>155$.

Rabyńka $<\mathrm{p} / \mathrm{r}>354$.

*Riczka, z Riczki 31, na lewym brzegu Riczki 261, z Riczki brusturskiej 245, „w Riczce-Krasnojyli, którą i do teraz Riczką Diduszkową zowią” 262, Riczki Diduszkowej (D) 262, aż na Riczkę diduszkową 269, nad Riczkę 262, ,jarami, wyżłobionymi przez burzliwe i niepewne Riczki” (pl) 328 .

* Rodna, Rodny (D) 326.

*Rokieta, ku Kosmaczowi i hen ku Rokiecie 378, na rozległej połoninie Rokiecie 311.

\#*Ropa-Uroczysko, z Ropy-Uroczyska 321, 350; na Uroczysko 563.

Rosiczny $<\mathrm{p} / \mathrm{r}>354$.

*Rozdroże, ,w tym właśnie miejscu, na Rozdrożu” 48.

*Rozszybeniak, na Rozszybeniaku 231.

*Roztoki, w Roztokach 215.

*Rożen, Rożna (D) 426, 427, 430, 513.

*Rożnów, do Rożnowa na Podgórzu 254, Rożnowa (D) 256, w Rożnowie 258.

*Ruski, niedaleko Ruskiego potoku 92, nad potokiem Ruskim 114, nad Ruskim potokiem 119, zaczęto rąbać lasy na Ruskim 118, na Ruskim 119.

* Rybnica, ku Rybnicy 496. 
Rzeka, przy ujściu potoków do Rzeki 47, nad Rzeka 135, „Rzeka jest błękitnosrebrna, a Riczka mlecznobiała. Rzeka toczy się z hukiem, a Riczka z dziarskim szemraniem" 422 [zob. też Czeremosz].

Siny (W) < potok $>223$.

\#Skit, do Skitu 284.

Skoruszny, na połoninie Skoruszny powyżej Zełenego 340.

Skupowa 445, pod pasmo Skupowej 329, ku pasmu Skupowej 335, na połoninę Skupowa 77, pod Skupowa 339, na Skupowej 445.

\#*Stoboda-Ropa, ze Stobody-Ropy 21.

*Słupejka, do potoku Stupejki (D sg) 396.

Smokowy $<\mathrm{p} / \mathrm{r}>354$.

*Smotrycz, na cyplach Smotrycza 178, na Smotryczu 75.

Sokolska skała, zaraz powyżej Kut Sokolska skała 331, do rubieży skały Sokolskiej (D) 331, pod Sokolska skała (N) 31, na skale Sokolskiej (Ms) 247; pod Sokolska górę (B) 390; do wierchu Sokolskiego 331, na wierzch Sokolski 331; na Sokolskim 332.

Sokołówka 257, Sokołówki (D) 256, 257, 427, 497, pod Sokołówkę (B) 255, chram na Sokotówce 256.

Srebrny $<\mathrm{p} / \mathrm{r}>354$.

*Stawiora, pod Stawiora 306.

*Stebne, ze Stebnego 422.

Stepanec, połonina Stepanec 221, ,stąd też i nazwa Stepanec, gdyż step znaczyło wówczas u nas wertep, miejsce niedostępne" 221.

Stoh, na połoninę Stoh 233, Połonina Stoh 234, sam Stoh jest bardzo łagodny i słoneczny 234, ze Stohu 236.

Studzienny $<\mathrm{p} / \mathrm{r}>354$.

*Sucha Syhla, poprzez Suchą Syhte 89.

*Sudija, przez Sudije 465, ,na innych, odległych połoninach na Sudiji” 245.

Suligul $(\mathrm{M} \leftarrow \mathrm{B}) 255$.

Sykawka, wodospad potoku Sykawka 401, nad wodospad Sykawkę 553, ,potoku, zwanego Sykawka" 331.

*Szuryn, Szuryna (D sg) 88, na Szurynie 88.

Synycie, całe Synycie słyszały 363, Synycie to nie góry czarodziejskie 327, na stokach Synyci 223, naprzeciwko północnego stoku Synyci 265, jak się schodzi z Synyci do Czarnej Rzeki 341, szedł od Synyci 264, podług Synyć 327, ku odległym Synyciom 230, przez Synycie 298, na Synycie 349, przez Synyci 339, za Synyciami 328, z Synyciami 329, na Synyciach 55, 90, 99, 222, 223, 244, 261, 298, 384, 392, w Synyciach 215, 269, 340, 373, o Synyciach 298, 468.

Szeszory 41 . 
Sziget (M־B) 91, Szigetu (D) 89, 107, 119, do Szigetu Marmaroskiego 88, w Szigecie 492, po Szigecie 91, w Szygiecie 448, w Syhocie na Węgrzech 82. Szpyci 480, pod Szpyciami 16, na Szpyciach 215, 461; teatry Szpyciowe 308.

Szybene, jezioro Szybene 202, „największe jezioro w Czarnohorze, Szybene, zwane w dawnych czasach Czuriek" 234, w Szybene jezioro 321.

Tekucza 41.

*Tiudiów, Tiudiowa (D) 513, pod Tiudiowem 441, pod Tiudowem 416.

*Torojaga, ku Torojadze 326, za Torojaga 379.

*Turkul, pod Turkułem 304.

Uścieryki 508, Uścieryk (D) 82, 90, 422, 426, 429, 507, Uścierykom (C) 64, 91, 508.

Waliło $<\mathrm{p} / \mathrm{r}>354$.

Waratyk, pod pasmem Waratyk 219, „na pierwszą połoninkę swoją, rodzimą - Waratyk" 310, w bukowinkach pod Waratykiem nad Białą Krynicą 277.

Warytyn 155, potok Warytyn 91, przez potok Warytyn 64, od potoku Warytyn 65, Warytynu (D) 65, Waratynem (N) 74, do rozdroża na Waratynie (Ms) 43, Warytynie (W) 354.

*Watonarka, przez przełęcz Watonarkę 274, nad Watonarka 275.

Wersałem <góra> 300, ku Wersałemowi 497, na Wersałemie 302.

Weselny $<\mathrm{p} / \mathrm{r}>354$.

\#*Wierbiąż, w Wierbiążu 248.

Wierchowina 185, 187, 232, 308, 311, 313, 317, Wierchowiny (D sg) 33, 36, 50, 54, 56, 63, 106, 139, 168, 170, 172, 184, 185, 228, 309, 316, ku Wierchowinie 169, Wierchowine (B) 270, 311, Wierchowina (N) 78, 303, na Wierchowinie (Ms) 20, 115, 133, 152, 310, o Wierchowinie (Ms) 32, 169; jak daleko sięgały okoliczne Wierchowiny (M pl) 91, Wierchowin (D pl) 15.

*Wolowe, z Wołowego $<$ osiedle $>424$.

*Worochta, między Kosmaczem a Worochta 245.

\#*Wyżnica, w Wyżnicy 106.

*Zabrodzie, na Zabrodziu 154.

Zawiź, do jaru zwanego Zawiź 117, „,w Zawizi, gdzie niegdyś góra zjechała” 92, na Zawizi 119.

Zełene (M־B), z Zełenego 21, powyżej Zełenego 340, dotarli na Zełene 396, na Zełeny 329.

Zmyjeński <p/r> 354, na Zmyjenski 486; z Połoniny Zmyjenskiej 234.

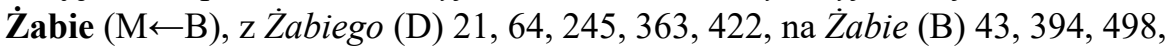
Żabiem (N) 300, 302, w Żabiem (Ms) 85, 105, 245, 364, 389, o Żabiem (Ms) 468, w Żabiu (Ms) 96, na Żabiu (Ms) 551. 


\section{Nazwy dzierżawcze in statu nascendi:}

do Doboszowej krynicy 27, bukowinka Szkindowa 333, bukowinka Palijowa 333, bukowinka Semenkowa 333, bukowinka Wasylukowa 333, źródło Szkindowe 337, na Kiczerę Szkindowa 481, na carynie Szumejowej 488.

\section{CECHY SYSTEMOWE TOPONIMII W „PRAWDZIE STAROWIEKU”}

Najogólniejszym wnioskiem dotyczącym systemowych cech językowych toponimii Huculszczyzny obecnej w I tomie „Na wysokiej połoninie” jest jej heterogeniczność - rozumiana tutaj jako współwystępowanie w badanym materiale zarówno nazw wyraźnie spolonizowanych, jak i nazw zachowujących wyraźne cechy ukraińskie lub gwarowe huculskie. Pod tym względem dzieło Vincenza nie wyróżnia się na tle większości tekstów polskich, w których toponimia regionu jest używana.

Zacząć wypada od najbardziej chyba charakterystycznej cechy fonologii ukraińskiej - ikawizmu. Zachowują go wprawdzie obecne u Vincenza formy przypadków zależnych Pohoriwki, Pohoriwkę, Psariwki, Psariwkę, jednak liczniejsze są adaptacje: Bednarówka, Bolechów, Jasienów, Kosów, Markówka, Sokołówka.

Dwoistość obecnych u Vincenza form narzędnika Tiudowem : Tiudiowem (wobec stałości formy dopełniacza Tiudiowa) ujawnia prawdopodobny wpływ polskiej fonetyki kresowej. Warto tu oddać głos S. Hrabcowi:

\footnotetext{
Różne postaci (...) tej nazwy pochodzą z różnych wyników zapożyczeń ukraińskiej formy T́ud'iu do języka polskiego, który zasadniczo nie zna $t^{\prime}$ i $d^{\prime}$. Raz więc $d^{\prime}$ przejęto jako $d \dot{z}$, stąd Tudziów. Polacy z Kresów Wschodnich stykający się z ukraińskim elementem językowym posiadają jednak w swym systemie fonetycznym głoski $t^{\prime}$ i $d$ ', stąd forma Tiudiów. W innych jednak wypadkach system fonetyczny polski oddziaływał na formę ukraińską mniej lub więcej silnie, usiłując usunąć miękkie $t^{\prime}$ i $d^{\prime}$ i zastąpić je twardymi $t$ i $d$, z czego powstały formy Tiudów lub Tudiów (Hrabec, 1950, s. 219).
}

Z kolei pisowniowa opozycja $e: y$ w formach Dancerskim, Dancyrskiej, Dancyrskiego, Dancyrza pozwala domyślać się zachowania obecnego w dialektach huculskich napiętego e, o którym J. Janów (1927, s. 74; wyróżn. - W.W.) pisał: „ślad wymowy rum. $\hat{\imath}$ występuje w huculskim dźwięku zbliżonym do $y^{e}$ (podwyższ., środkowe-zewnętrzne napięte $e$ ), który zapisywacze oddają częściej przez $\boldsymbol{y}$ niż przez $\boldsymbol{e}$ ". Analogiczny problem polegający na trudnościach $\mathrm{z}$ obsłużeniem huculskiego/ukraińskiego inwentarza fonetycznego przez polskie (ortograficzne) zasady transformacji fonemiczno-grafemicznych występuje w wypadku pisowni Dothopole i Dowhopola (ukraiński systemowy odpowiednik polskiego $v$ jest albo „transkrybowany” jako $t$, albo „transliterowany” jako $w)$. 
Cechy gwarowe huculskie obecne są też w konsekwentnie używanej w ,Prawdzie starowieku” postaci nazwy Koszeryszcze, a szczególnie w apelatywie kosziery (M pl). Jak zauważa S. Hrabec (1950, s. 227), postać huculska nazwy to Koš́eryše, zaś postać ogólnoukraińska to Košaryšče. W wymowie gwarowej pierwsze $e$ bierze się z przejścia $a>e$ po spółgłosce palatalnej, pierwsze $\check{s}$ jest wynikiem silnej gwarowej palatalizacji ogólnoukr. $\check{s}$, natomiast drugie $\check{s}$ to

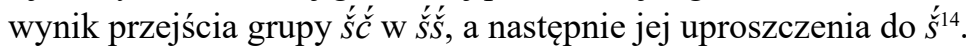

Postać używana przez Vincenza (Koszeryszcze) łączy więc huculskie przej-

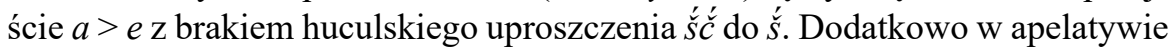
kosziery polską ortografią oddana została miękkość $\breve{s}$.

Przypadkiem polskiej ortografii dokumentującej wymowę ukraińską jest zapis formy dopełniacza Kraśneho $Ł u h u$.

Poza wyżej przywołanym przykładem n. m. Tiudiów międzysystemowa heterogeniczność toponimii widoczna jest w kontekście zmiękczeń i twardości dźwięków w formach takich jak: Jasienowie (Ms) : Jasieniowie (Ms); Kremenystym (N) : Krzemienistem (N) : Krzemienistym (N); Kremenicy (D) : Kremienicy (D). Na tle tych wahań uwagę zwraca w pełni konsekwentna zmiękczająca polonizacja obu $v$ w postaci n.m. Wierchowina.

Na płaszczyźnie słowotwórczej uwagę zwracają izolowane formy nazw miejscowych na -owo (względem -ów, jakiego należałoby się spodziewać zarówno wobec geograficznej dystrybucji polskiego -owo/-ów, jak i wobec ukr. -ib): Jasienowo - wobec także występującego w tekście Jasienów - oraz Jaworowo.

Także nazwy, którym w obu językach odpowiadają homonimiczne apelatywy, pojawiają się u Vincenza w postaci polskiej i ukraińskiej. Wśród nazw „przetłumaczonych” wymienić można toponimy: Biała Kobyła, Biała Krynica, Biała Rzeka, Pisany Kamień, Krzesło Doboszowe, zaś wśród nazw „nieprzetłumaczonych": Czerłeny, Zetene, Zełeny, Cerkwy.

Poprawną huculską charakterystykę gramatyczną (liczba mnoga) ma oronim Synycie, przy czym oboczności widoczne są w wypadku dopełniacza Synyci : Synyć, oraz biernika Synycie : Synyci. Sama użyta forma mianownikowa nosi wszak ślad pewnej drobnej adaptacji — jak podaje S. Hrabec (1950, s. 227) brzmienie gwarowe nazwy to Synyc' $i$, zaś dopełniacz - Synyc.

Ponadto szczególną wariantywnością odznacza się w tekście Vincenza nazwa dzisiejszego Sighetu Marmației, występująca w dopełniaczu w postaciach Szigetu, Szigetu Marmaroskiego, w bierniku jako Sziget, a w miejscowniku jako Szigecie, Szygiecie i Syhocie.

${ }^{14}$ Kwestię huculskiej palatalności $\check{s}, \check{z}, \check{c}$ i $\check{s} c ̌$ oraz uproszczenia $\stackrel{s}{s} \check{c}>\stackrel{s}{s}$ dokładniej opisuje J. Janów (1928, s. 279-280). 
Ostatnią opozycją cech systemowych, na jaką tutaj warto zwrócić uwagę, jest konsekwentne używanie przez Vincenza niespolonizowanej postaci nazwy góry/grzbietu Kostrycz (wobec mającego dzisiaj — jak się wydaje — pewną przewagę w uzusie polskim Kostrzyca), przy jednoczesnym konsekwentnym użyciu w pełni spolonizowanej nazwy wsi, w której autor "Prawdy starowieku” spędził dzieciństwo, Krzyworównia (wobec praktycznie w ogóle nieobecnego w polskich tekstach Kryworiwnia). W wypadku form Bystrzec : Bystrec widać natomiast u Vincenza stałą wariantywność.

\section{KREACJE NAZEWNICZE?}

W „Prawdzie starowieku” pojawiają się też „polskie” nazwy, dla których brak powszechniejszych poświadczeń tekstowych. Można z jednej strony dopatrywać się tu swoistych zabiegów stylizacyjnych, z drugiej zaś strony realizacji pewnych potrzeb nazewniczych (idzie o nazwy grup górskich), których tradycyjna toponimia nie zaspokajała. Tworzy więc Vincenz — nieznane niżej podpisanemu z innych tekstów — nazwy takie jak: góry czeremoskie, góry Polańskie i góry Ruspolańskie ${ }^{15}$.

Uwagę zwraca ponadto adaptacja (obecnie funkcjonującej) nazwy Ясіня do postaci Jasień węgierski i Jasień Węgierski lub po prostu Jasień. O prawdopodobnej stylizacji świadczy w tym wypadku to, że w innej swojej książce, „Dialogach z Sowietami” pisze Vincenz o „wsi Jasina, którą niedawno ponownie nazwano Körösmezö" (tak w książce, poprawnie węg. Körösmezö).

\section{INNE WŁAŚCIWOŚCI TOPONIMII HUCULSZCZYZNY \\ W „PRAWDZIE STAROWIEKU”}

Pierwszy tom „Na wysokiej połoninie” stanowi w wielu wypadkach ciekawe tekstowe poświadczenie specyficznych (nie tylko stricte systemowych, słowotwórczych czy etymologicznych) właściwości toponimii Huculszczyzny, jakie stwierdził S. Hrabec w swoich badaniach (przypadających na 2. połowę lat 30. $\mathrm{XX}$ w.). Część tych wniosków (np. dotyczące motywacji i chronologii nazw) jest stała, część zaś (np. spostrzeżenia dotyczące polireferencyjności) mogła się w pewnym stopniu zdezaktualizować. Powstanie tekstu „Prawdy starowieku” bezpośrednio sąsiaduje jednak z badaniami Hrabca (w tym terenowymi), którego konstatacje można zilustrować materiałem wydobytym z dzieła Vincenza.

15 Dwie ostatnie nazwy odnoszą się do gór wokół wsi Poienile de sub Munte, która w wydobytym materiale obecna jest pod nazwą Poleny wegierskie. 
Cechą ogólną (w większości stosunkowo młodej) toponimii Huculszczyzny była pierwotność licznych nazw gruntowych względem tożsamych lub podobnych nazw obiektów innych kategorii (m.in. rzek, potoków i szczytów) — powiązana z częstymi przypadkami wieloznaczności nazw (por. Hrabec, 1950, s. 93, 97-98, 163, 225).

Zwrócić trzeba tu raz jeszcze uwagę na dużą płynność faktu odnoszenia się danej nazwy do określonego obiektu geograficznego. Ponieważ potok (ukr. p'ot'ik) ma również znaczenie 'gruntu w dolinie potoku położonego', a grunt leży na stoku góry, nie wiadomo niekiedy, czy nazwa odnosi się do wody, gruntu czy góry. W wielu wypadkach — do wszystkich trzech obiektów geograficznych równocześnie. (...) Tego rodzaju nazwy są pierwotnie po prostu nazwami „miejsc geograficznych” ze wszystkimi ich geograficznymi szczegółami (Hrabec, 1950, s. 226).

W tym świetle zwracają uwagę następujące nazwy wydobyte z ,Prawdy starowieku" (wraz z towarzyszącymi im kontekstami): Hostowy — sygnuje potok, szczyt i połoninę, Ihrec - górę/szczyt i połoninę, Kamieniec — połoninę i górę (,ze stromego zbocza Kamieńca”), Kizia — potok, połoninę i grunt (,wody Kiziej ze skał spływają”, „na połoninie Kiziej”, „na Kiziej nie będzie już połoniny pańskiej”), Ruski — potok i dolinę/stok/grzbiet (,zaczęto rąbać lasy na $R u$ skim”), Skupowa - szczyt/górę (,pod pasmo Skupowej”) i połoninę.

Toponimia obecna u Vincenza nakazuje zacytować jeszcze jedną konstatację Hrabca:

Bardzo częstym sposobem nazywania wód jest użycie do tego celu wyrazu pospolitego ozna-
czającego wodę, rzekę, potok itp. Zachodzi to szczególnie wtedy, gdy w okolicy znajduje się
tylko jeden obiekt, który może być tym wyrazem pospolitym nazwany. Wtedy same warun-
ki terenowe sprawiają, że wyraz pospolity (apelatywum) staje się imieniem własnym (nomen
proprium). Jeżeli w okolicy znajduje się więcej podobnych obiektów, to do wyrazu pospolitego
dodaje się człon drugi, odróżniający (...) (Hrabec, 1950, s. 57).

Tutaj wspomnieć trzeba, że tekst Vincenza dochowuje wierności lokalnemu huculskiemu kontekstowi toponimicznemu, w którym Czeremosz zwany był po prostu Rzeka, Czarny i Biały Czeremosz — odpowiednio Czarna i Biała Rzeka, zaś w celu wyróżnienia biegu połączonych Czeremoszów mówiono o Dolnej Rzece - por. w materiale wypisy dla Biała Rzeka, Czarny Czeremosz i Rzeka.

W wypadku nazw motywowanych przez te same apelatywy w celu odróżnienia obiektów możliwe było stosowanie derywacji, co dawałoby ukr. parę Piкa і Річка. W tym kontekście u Vincenza zwraca uwagę nałożenie się na tę opozycję dodatkowo opozycji „tłumaczenia” i „cytatu” nazwy: „Rzeka jest błękitnosrebrna, a Riczka mlecznobiała. Rzeka toczy się z hukiem, a Riczka z dziarskim szemraniem". 
S. Hrabec (1950, s. 225) podkreśla ponadto, że istotną cechą toponimii $\mathrm{Hu}-$ culszczyzny jest bogactwo nazw dzierżawczych. Ilustracją tego są nazwy podane na końcu materiału jako „nazwy dzierżawcze in statu nascendi”.

Wobec językoznawczych ustaleń S. Hrabca toponimia „Prawdy starowieku” wydaje się więc autentyczna - użycie nazw przez Vincenza wpisuje się bowiem w ogólne właściwości funkcjonowania nazewnictwa geograficznego regionu w okresie powstania „Połoniny”.

\section{DEKLINACJA WYBRANYCH TOPONIMÓW}

Współcześnie dla użytkowników języka polskiego kłopotliwe deklinacyjnie są m.in. nazwy Bystrzec, Żabie i Pop Iwan. Warto się więc przyjrzeć odmianie tych właśnie toponimów w dziele Vincenza.

Wydobyte z „Prawdy starowieku” formy deklinacyjne toponimu Bystrzec/Bystrec układają się w następujące paradygmaty:
M. Bystrzec
Bystrec
D. Bystrzeca
Bystreca
C. Bystrzecowi
$-(=$ M. $)$
B. $-(=$ M. $)$
Bystrecem
N. -
$-$

Wariantywność mianownika i idąca za nią wariantywność form przypadków zależnych idealnie pokrywa się z wahaniami obecnymi w polskich tekstach. Podobnie typową dla tekstów języka polskiego wariantywność schematu odmiany można w tekście Vincenza znaleźć w wypadku nazwy miejscowej Żabie, której wynotowane formy układają się następująco (wobec Ms. Żabiu zwraca uwagę brak D. Żabia):
D. Żabiego/
B. Żabie / Żabie
N. Żabiem /
Ms. Żabiem /
$\dot{Z} a b i u$

W tekście „Prawdy starowieku” zaskakuje bardzo mała frekwencja oronimu Pop Iwan. Niżej podpisany znalazł zaledwie cztery jego wystąpienia. I choć dominuje wśród nich popularniejsza w przedwojennym uzusie polskim nieodmienność członu Pop, to w jednym wypadku przypuszczalna atrakcja rzeczownika pospolitego pop doprowadziła jednak do postaci dopełniacza Popa Iwana. 
W tym kontekście warto też zwrócić uwagę na odmianę oronimu Gutyn Tomnatyk, w którym pierwszy człon jest unieruchomiony fleksyjnie, natomiast odzyskuje odmienność, gdy występuje samodzielnie.

\section{ETYMOLOGIE W „PRAWDZIE STAROWIEKU”}

„Na wysokiej połoninie” łączy w sobie „kodyfikację” ludowych podań huculskich z głęboką filozoficzną i humanistyczną refleksją autora. A ponieważ Vincenz sam posiadał filologiczne wykształcenie, ciekawie wypada przegląd etymologii (częściowo ludowych), jakie uwzględnił on, objaśniając w „Prawdzie” pochodzenie niektórych toponimów.

Podaną przez Vincenza etymologię (zob. cytaty w materiale) oronimu Ihrec skomentował S. Hrabec (zob. cyt. w sekcji „Na wysokiej poloninie” jako źródło...). Sugerowany źródłosłów oronimu Baba Lodowa względnie Baba Łudowa (od lód i łudzić) wydaje się mieć charakter etymologii ludowej (np. S. Hrabec 1950 , s. 165 , zestawia ją z rum. lud 'prosty, prostacki') — por. też przyp. 12. Zupełnie fantastyczny charakter ma zapewne objaśnienie pochodzenia n. m. Hołowy (S. Hrabec, 1950, s. 187, widzi tu raczej związek z terminem topograficznym holovyc'ia 'źródło'). Badacz ten (1950, s. 196) potwierdza natomiast obecną u Vincenza wersję łączącą ojkonim Krasnoila (u Vincenza Krasnojyla) z piękna jodła. Całkowicie trafne jest objaśnienie nazwy Prosicznyj łączące ją z przesieka. Wątpliwości budzi zaś sugerowane w „Prawdzie starowieku” pochodzenie nazwy Stepanec, którą łączyć by wypadało raczej z n. os. Stepan (por. Hrabec, 1950, s. 182).

\section{POLITYKA NAZEWNICZA}

Czy pod względem cech systemowych (polskich, ukraińskich, huculskich) toponimię obecną w „Prawdzie starowieku” można uznać za wyraz pewnej polityki nazewniczej autora? Brak tu miejsca na wyprowadzenie ścisłej definicji pojęcia polityki nazewniczej, ale przy intuicyjnym rozumieniu terminu można postawić hipotezę (lecz nie tezę - poruszamy się tu wszak po płaszczyźnie zamiarów, które zawsze pozostają zamknięte w subiektywnej sferze psychicznej działającego podmiotu), że użycie przez Vincenza toponimii, która jako zbiór pod względem właściwości językowych ma hybrydalny charakter międzysystemowy, wpisuje się w wieloetniczność perspektywy, z jakiej Vincenz sportretował w swym dziele Huculszczyznę. Ponadto, jak zaznaczono na wstępie, celem niniejszej pracy jest przede wszystkim zestawienie i opis materiału przewidziany do wykorzystania w dalszych analizach z zakresu teorii polityki nazewniczej. 


\section{PODSUMOWANIE}

W toponimii „Prawdy starowieku” jak w soczewce skupia się złożoność językowych i nazewniczych kontaktów i relacji polsko-ruskich. Pod tym względem dzieło Vincenza w pełni wpisuje się w hybrydalność i heterogeniczność używanych w tekstach języka polskiego nazw geograficznych obiektów z obszaru Huculszczyzny. Autor „Połoniny”, pozostający przez długie lata we wspólnocie komunikatywnej z Hucułami, utrwalił w swym tekście pewne autentyczne cechy społecznego funkcjonowania toponimii Huculszczyzny w okresie powstawania „Prawdy starowieku”, przy czym idzie tu przede wszystkim o homonimiczność, względnie polireferencyjność wielu nazw pierwotnie gruntowych i znaczny udział nazw dzierżawczych. Swoją try- względnie tetralogię pisał jednak Vincenz po polsku, więc w wielu wypadkach korzystał z utartych sposobów polonizowania nazw ukraińskich. „Prawda starowieku” w żadnym razie nie jest przesycona zabiegami stylizacyjnymi, których istotą byłoby dążenie do używania nazw-cytatów, a więc form toponimicznych możliwie najwierniej zachowujących cechy językowe huculskiej endonimii.

\section{LITERATURA}

Czopek, B. (1988). Nazwy miejscowe dawnej ziemi chełmskiej i bełskiej (w granicach dzisiejszego państwa polskiego) [Place Names of the Former Chełm and Bełz Land (Within the Borders of Present-day Poland)]. Kraków: Zakład Narodowy im. Ossolińskich, Wydawnictwo Polskiej Akademii Nauk.

Decyk-Zięba, W. (2004). Nazewnictwo wschodniosłowiańskie w języku polskim XVI i początku XVII wieku [East Slavic Names in the Polish Language in the 16th and the Early 17th Century]. Warszawa: Nakładem Wydziału Polonistyki UW.

Hrabec, S. (1950). Nazwy geograficzne Huculszczyzny [Geographical Names of the Hutsul Region]. Kraków: Polska Akademia Umiejętności.

Janów, J. (1927). Ze stosunków językowych rusko-rumuńskich [Remarks on the Ruthenian-Romanian Language Relations]. Sprawozdania Towarzystwa Naukowego we Lwowie, r. VII, z. 2, s. $72-77$.

Janów, J. (1928). Z fonetyki gwar huculskich [Remarks on the Phonetics of the Hutsul Dialects]. W: Symbolae grammaticae in honorem Ioannis Rozwadowski [Linguistic Festschrift in Honour of Jan Rozwadowski]. T. II. (s. 259-290). Kraków: Gebethner \& Wolff.

Makarski, W. (1986). Nazwy miejscowości dawnej ziemi sanockiej [Place Names of the Former Sanok Land]. Lublin: Redakcja Wydawnictw KUL.

Ołdakowska-Kuflowa, M. (2006). Stanisław Vincenz. Pisarz, humanista, orędownik zbliżenia narodów. Biografia [Stanisław Vincenz. Writer, Humanist, Advocate of the Rapprochement of Nations. A Biography]. Lublin: Towarzystwo Naukowe Katolickiego Uniwersytetu Lubelskiego Jana Pawła II.

Pluskota, T. (1998). Nazwy miejscowe ziem ruskich Rzeczypospolitej XVI-XVIII w. Toponimia Ukrainy i pogranicza polsko-ukraińskiego [Place Names of the Ruthenian Lands of the Pol- 
ish-Lithuanian Commonwealth in the 16-18th Centuries. Toponymy of Ukraine and the Polish-Ukrainian Borderlands]. Bydgoszcz: Wyższa Szkoła Pedagogiczna.

Rieger, J. (1993). Elementy ukraińskie w toponimii polskiej i w toponimii Polski [Ukrainian Elements in Polish Toponymy and in the Toponymy of Poland]. Acta Universitatis Lodziensis. Folia Linguistica, 27, s. 247-253.

Rieger, J. (1994). Niektóre problemy toponimii Ukrainy w XVI w. [Some Issues of the Toponymy of Ukraine in the 16th Century]. Onomastica, XXXIX, s. 117-129.

Rieger, J. (1995), Słownictwo i nazewnictwo łemkowskie [Lemko Vocabulary and Names]. Warszawa: Wydawnictwo Naukowe Semper.

Rymarowicz, L., Zełenczuk, I., Zełenczuk, J. (2016). Połahna - Stanisława Vincenza przewodniczka po huculskiej duszy [Polahna - Stanisław Vincenz's Guide to the Hutsul Soul]. Płaj, 52, s. 47-50.

Vincenz, A. (1983). Posłowie [Afterword]. W: S. Vincenz, Na wysokiej połoninie. Barwinkowy wianek [On the High Uplands. A Garland of Periwinkles] (s. 550-564). Warszawa: Instytut Wydawniczy PAX.

Włoskowicz, W. (2015). Toponimia Huculszczyzny na austro-węgierskich i polskich mapach topograficznych (od poł. XIX w. do 1939 roku) [Toponymy of the Hutsul Region on Austro-Hungarian and Polish Topographic Maps from the mid-19th Century to 1939]. W: I. Valentová (red.). 19. slovenská onomastická konferencia. Bratislava 28.-30. apríla 2014 [19th Slovak Onomastic Conference. Bratislava 28-30 April 2014] (s. 298-307). Bratislava: VEDA, vydavatel'stvo Slovenskej akadémie vied.

Włoskowicz, W. (2017). Uzus toponimiczny. Zarys problematyki teoretycznej (na podstawie polskiej toponimii Huculszczyzny) [Toponymic Usus. An Outline of Theory (on the Basis of the Polish Toponymy of the Hutsul Region)]. Rozprawa doktorska przygotowana pod kierunkiem prof. dr hab. Ewy Wolnicz-Pawłowskiej.

Włoskowicz, W. (2018). Toponymie des Huzulenlandes in der österreichischen Kartographie vom Ende des 18. Jahrhunderts bis 1918 [Toponymy of the Hutsul Region in Austrian Cartography from the late 18th Century to the year 1918]. Jahrbuch des Wissenschaftlichen Zentrums der Polnischen Akademie der Wissenschaften in Wien, 9, s. 237-267.

Wolnicz-Pawłowska, E. (1998a). Pogranicze wschodnie [The Eastern Borderland]. W: E. Rzetelska-Feleszko (red.). Polskie nazwy własne. Encyklopedia [Polish Proper Names. Encyclopaedia] (s. 453-466). Warszawa-Kraków: TNW - IJP PAN.

Wolnicz-Pawłowska, E. (1998b). Pogranicze południowe [The Southern Borderland]. W: E. Rzetelska-Feleszko (red.). Polskie nazwy własne. Encyklopedia [Polish Proper Names. Encyclopaedia] (s. 467-478). Warszawa-Kraków: TNW - IJP PAN.

Wolnicz-Pawłowska, E. (2001). Toponimy w „ruskich” tomach „Dzieł wszystkich” Oskara Kolberga [Toponyms in the "Ruthenian" Volumes of "The Collected Works" by Oskar Kolberg]. W: A. Cieślikowa, B. Czopek-Kopciuch (red.). Toponimia i oronimia [Toponymy and Oronymy] (s. 177-188). Kraków: Wydawnictwo Naukowe DWN.

Wysoczański, W. (2006). Odniesienia międzyjęzykowe w świetle nazw miejscowych pogranicza polsko-ruskiego [Interlingual References in the Light of Toponyms of Polish-Ruthenian Borderland]. Acta Polono-Ruthenica, 11, s. 307-329. 


\section{SUMMARY}

GEOGRAPHICAL NAMES OF THE HUTSUL REGION IN THE FIRST VOLUME OF THE NOVEL “ON THE HIGH UPLANDS” BY S. VINCENZ (IN LIGHT OF S. HRABEC'S RESEARCH)

The aim of the paper is to discuss the linguistic and onymic properties of the geographical names of the Hutsul region (Гуиульщина, Ukraine) used by Stanisław Vincenz in the first volume ("Prawda starowieku") of his tetralogy "Na wysokiej połoninie" ("On the High Uplands"). The volume was first published in 1936. The second edition appeared in 1980 in Poland and was the one which had the greatest impact on the reception of the Vincenz's work in the Polish readership after WW2. This is why the 1980 edition has been used as the source of analysed toponymic material. The main finding is that the analysed toponymy is of heterogeneous and (to a certain extent) hybrid nature, combining Polish, Ukrainian, and dialectal Hucul linguistic properties, which perfectly coincides with general tendency in the use of geographical names of the Hucul region in texts produced in the Polish language from the mid-19th century. The names used by Vincenz in the book written in the period 1930-1936 seem to faithfully reflect some specific characteristics of Hutsul toponymy in the 1930s (as discussed by the linguist Stefan Hrabec in his dissertation). Finally, some instances of toponyms' declension present in "Prawda starowieku" are discussed together with some examples of (partially folk) etymologies codified by Vincenz in his work.

Keywords: toponym, geographical name, Vincenz, Hutsul region, "On the High Uplands" 